\title{
ACC and ACCID: Two Accounting Associations from Catalonia, 80 years apart
}

\author{
Nuria Arimany-Serrat ${ }^{1}$ (D), Carme Viladecans-Riera ${ }^{1}$ (D), Pilar Morera-Basuldo ${ }^{2}$ (D) \\ ${ }^{1}$ Universitat de Vic (Spain) \\ ${ }^{2}$ Universitat de Girona (Spain) \\ nuria.arimany@uvic.cat,carme.viladecans@uvic.cat,pilar.morera@udg.edu
}

Received November, 2019

Accepted December, 2019

\begin{abstract}
Purpose: Retrospective study of associationism and accounting knowledge in Catalonia, during the period 1924-1940, through the analysis of the journal Organització, published by the Associacio de Comptables de Catalunya (ACC, Catalonian Association of Accountants). Comparison between the ACC and the Associació Catalana de Comptabilitat I Direcció (ACCID, Catalonian Association of Accounting and Management), to highlight the evolution of the accounting profession in Catalonia over the course of one century.
\end{abstract}

Design/methodology: Exploratory study of each issue of the journal Organitzacio during its period of publication (1925-1938) and a review of the literature in the area being studied. Processing of the information obtained through dynamic tables, to obtain the results and conclusions of the research conducted. Exploratory comparison of the ACC and ACCID.

Findings: The study highlights the work carried out by the ACC during its existence, as the driving force behind the accounting profession in Catalonia, and relations with other international associations. It also establishes a parallelism with the ACCID.

Research limitations/implications: Slow access to all the issues of the journal Organitzacio in order to create the corresponding technical files of the works collected in each journal and difficulty in finding ACC documentation in the literature review.

Practical implications: This work highlights the work of professionals in the field of accounting in the 20 th and 21st centuries, showing the need for accounting regulations, continued training and internationalization to meet the demands of the business world.

Social implications: It makes professionals and scholars in the field of accounting aware of the importance of the work carried out by the ACC in the first half of the 20th century, and the harmony with the work currently carried out by the ACCID.

Originality/value: The study draws attention to the activity carried out by the ACC, unknown at the time of the founding of the ACCID, and shows that at certain times, associations of accountants have been important on a business level.

Keywords: Associació de Comptables de Catalunya (ACC), Associació Catalana de Comptabilitat i Direcció (ACCID) 


\section{Jel Codes: M41}

\section{To cite this article:}

Arimany-Serrat, N., Viladecans-Riera, C., \& Morera-Basuldo, P. (2020). ACC and ACCID: Two Accounting Associations from Catalonia, 80 years apart. Intangible Capital, 16(2), 45-60. https://doi.org/10.3926/ic.1555

\section{Introduction}

This work refers to a retrospective study of associationism and accounting knowledge that were found in Catalonia during the period 1924-1940.

Specifically, the study aims to disseminate the research of a group of people from ACCID, in reference to the Associació de Comptables de Catalunya (ACC), following an article by Marc Amat in Revista de Catalunya in issue 288 (Amat, 2014), exploring the journal that was published monthly by the ACC for its members, called Organització.

The study presented here is an analysis of the information contained in the journal Organitracio, title of the journal of the Associació de Comptables de Catalunya (ACC), which was published from 1925 to 1938. The Associació de Comptables de Catalunya (ACC), was an institution which, among other things, shared accounting knowledge amongst its members. The Journal Organització was the medium through which the ACC informed its members. It also gathered advertising from the time, and its director was usually the president of the Associacio de Comptables de Catalunya. The journal contained articles on accounting (together with the position of the accountant), economics, business organization and law (commercial, fiscal and financial). It was a technical journal in the field of accounting that promoted associationism and offered free consultations to the members of the ACC. It published directives of interest to the readers, posted job requests by members, reported on conferences and also gathered advertising in order to finance itself.

This work briefly explains the endeavors of the association and conducts an exploratory study of its journal Organització, highlighting its content, as well as how accounting and business issues were addressed at that time and the significant advances made in the professional field that it reported on, and which are mostly unknown today.

A chapter of this study has been dedicated to comparing the ACC and ACCID in terms of their organizational structure, activities, members and publications, among other aspects, in order to verify the existence of a close parallelism between the two associations.

The exploratory study also reflects the international vocation of the ACC - in line with that of today's Associacio Catalana de Comptabilitat I Direcció (ACCID) - as demonstrated by the organization of the first International Accounting Conference, taking advantage of the 1929 Barcelona International Expo, highlighting the importance and economic significance of this type of event in the field of accounting and business. The study also highlights the importance of the relationships that the ACC established with other international accounting organizations.

The study in the journal Organitzacio also refers to the authors who published in it, such as accounting professionals, managers and experts of the time who provided knowledge to those interested.

Thus, the work seeks to make visible the importance that the ACC had as a driving force in the accounting profession during the first half of the 20th century, which the ACCID has subsequently continued sixty years later. 


\section{The Associació de Comptables de Catalunya. A brief history}

On February 12, 1924 the Associació de Comptables de Catalunya (ACC) was founded in Barcelona. Its main objective was to create a space to debate and work on accounting issues, among accounting professionals and employees in Catalonian commerce and industry who were members of the ACC.

This association carried out a number of activities, including the following:

- The journal Organització: It is worth mentioning the journal published by the association, called Organització. It came out on a monthly basis, and allowed the association to provide visibility to the activities it engaged in. It began publication in July 1925 and ended its run in 1938. It offered articles on accounting, economics, law, taxation, organization and other related areas. There was also a section in which provisions and regulations of interest to the members were published, another section with job requests by the collaborators, information on the association's participation on an international level, consultations regarding accounting and tax issues by the partners, etc. The journal also had sections meant for advertising spots, basically related to accounting.

- Other Publications: Books and documents referring to the activities carried out by the ACC were published.

- Training: Courses and conferences were organized for its members on current topics, especially on accounting, business, arithmetics, languages, law and economics.

- Advertising: Its activities were basically advertised through the journal Organització.

- Consultations: Agreements with professional firms were established so members could consult on accounting, tax and other issues.

- International: The activity was not limited only to Catalonia, rather it also had an international projection, with association members attending international conferences and with the celebration of the 6th International Accounting Conference in Barcelona in late 1929. This event was described in great detail in issue 53-54 of the journal (November and December 1929).

- Library: It had its own library that made it possible to purchase books and subsequently lend them to its associates.

- Job bank: Where job offers and requests were published for members.

- Mutual Society Services: It was considered advisable for members and interested family members to have financial coverage in case of illness, disability and death.

When the civil war ended in Spain and the Franco regime began around 1940, the ACC ceased to exist.

\section{Review of the literature}

Technological breakthroughs are changing the dynamics of many sectors of economic activity and professional services, and accounting is no exception. To face this change, it is important to have a historical perspective of this discipline and know how the accounting profession has evolved over time (Carmona, 2004). This review highlights the ACC and ACCID, as two accounting associations 80 years apart in a European context concerned with accounting standardization, among other issues.

The 19th century was a period of change in accounting. Fraud spotlighted the need for accounting control and profit became a major social issue, and so standardization began to be a priority (Lemarchand \& Praquin, 2005). From 1880 on, accountants and lawyers reflected on the need for rules on accounting information, its control and the future of the accounting profession, but their voices largely went unheard. Later, with the creation of the Society of Accountants in Paris in 1912, this issue was given a little more prominence, until the mid-1930s when legislation on accounting was ultimately introduced. During this period, as the accounting profession 
became more important, the ACC played an important role in Catalonia, in particular at the 6th International Accounting Conference in Barcelona in 1929, organized by the Association Internationale de Comptabilité of Brussels. With outstanding participation by the ACC, a universal accounting doctrine was proposed, to make accounting more uniform and comparable (Lemarchand \& Praquin, 2005). During this period, 10 international conferences were held from Bucharest to Barcelona (Forrester, 1992).

It should be kept in mind that the 1930 crisis recommended an accounting standardization that was not shared by all. Specifically, France failed to approve regulations for accounting standardization. However, between 1936 and 1937, these regulations came to fruition in Germany, due to the influence of the State on the economy (Richard J., 1992; Küpper \& Mattessich, 2005). Different associations were founded, including the Union of International Associations (UIA), the Academic Accounting Society of Belgium (AASB) and the International Accounting Association (IAA) (Félix, 2011).

In France, the influence was felt not only of political power, but also at the professional level. Along this line, Maurice Allais, a mining engineer, recommended this standardization to improve economic efficiency, ensure competition and eliminate fraud, opening the way for a new economic organization (Allais, 1938; Allais, 1956). At this time, the idea of accounting standardization was spreading. Moreover, insurance companies followed this pattern at the end of 1938, presenting an annual report with the balance, results and investments, when required by the relevant administration (Lemarchand \& Praquin, 2005).

During this period, the ACC published the journal Organització and maintains contact with different associations and associated accountants from different countries, such as England, Germany and France. It also held periodic meetings at conferences, where members of the associations examined and analyzed the accounting and economic problems of the time (Amat, 2014). Eighty years later, the Associació Catalana de Comptabilitat I Direcció and Auditoria de Comptes continue the path of the ACC, with the similarities and differences that are reported in this work.

There are different authors who stand out on an international level in terms of accounting in this period: Dregrange, Léautieu, Guilbault, Dupont, Howard, De Roover, Gomberg, Delaporte and Dupont (Degos \& Mattessich, 2003a; Degos \& Mattessich, 2003b). Joseph H. Vlaemminck (1961), a well-known Belgian, stated that accounting responds to business needs through proprietary information, with a significant impetus towards standardization and record keeping. It is important to keep in mind that it is a Belgian academic association and subsequently, a world accounting association (created at the 1910 World Exhibition in Brussels) that promote standardization and encoded accounting data (Forrester, 1992).

\section{Exploratory study of the journal Organització}

The methodology used consisted of an exploratory study that aims to provide a general overview of the contents of the journal Organització during its existence from 1925 to 1938, by means of a study of each of its issues. This topic of analysis has not been widely studied, explored or recognized. For this reason, the intent is to recall the topics and authors who dealt with momentous aspects in the field of accounting and finance during this period. In order to increase the degree of familiarity with this practically unknown journal, technical sheets have been created for the content of each issue (Appendix A). This has made it possible to give visibility to and assess the advances in the business, accounting and professional framework of this period in Catalonia, and the business behavior on an accounting and financial level in earlier times with less information in this field.

The methodology has consisted of a detailed analysis of each issue, the topics covered and the authors of the time, in order to reflect the dynamism of the territory, with important changes as a result of the historical situation. The journal, available at the Biblioteca Nacional de Catalunya and at the ACCID headquarters, was scanned and the different copies, distributed among the working group, were summarized on the appropriate technical sheets. Subsequently, using Excel sheets and dynamic tables, the typology of the main subjects dealt with and the authors of reference were presented, in line with the history of accounting in that period, and together with the results and conclusions. 
The study was carried out to recover the historical memory of a journal in the field of accounting (the area of knowledge of the co-authors), which was up to date with innovations in the business and accounting field on a national and international level.

As is typical of an exploratory study, it identifies trends and provides the basis for a business philosophy that is open to the world. Issue after issue, this journal reflects the situation at the time, the most interesting business topics of the period and the different professional and academic events of this period of time within the ACC. It should be remembered that during those years, other entities dealt with business issues, such as the Mercantile Circle, professional associations (qualified financial experts, accountants, lawyers), business schools, institutions of higher education and private centers.

Regarding the results of the exploratory study, Section 6 of this article reflects the contents of the journal Organització.

The described methodology has made it possible to identify the topics that were given priority at that time (accounting records, economics, trade law, taxation and associationism), among others, and the authors of the time who were interested in these areas of knowledge.

\section{Characteristics and structure of the journal Organització}

It is cataloged as a thematic journal because it is a monthly publication with information on a specific topic (the company), offering articles with detailed explanations.

\subsection{Characteristics}

This section lists the basic characteristics of the journal:

- It can be cataloged as direct, since it is a publication aimed especially at readers interested in business vicissitudes (basically business professionals) in any of their aspects, and in particular, at ACC members. For this reason, it contains a wide variety of articles.

- It is published on a monthly basis. The first issue was published in July 1925. In general, one issue was published each month, although some publications combined two or more periods. Number 149 was the last to be published, and it covers the months of March, April and May 1938. It is important to keep in mind that the Spanish Civil War was taking place during this period. The correlation of years and numbers published can be seen in Appendix B.

- It was specialized in the topics of all branches of business activity, as will be commented on in the fifth section, where the contents of the magazine are discussed. Scientific and technical knowledge is disseminated in an understandable and enjoyable manner.

- It was carefully edited, although it was difficult to obtain people's collaboration to be able to share the knowledge with the rest of professionals. The journal sought not only direct contributions, but also presentations by foreign experts and connoisseurs of any of the branches that are included in the business activity.

It is a journal closely related to the activities carried out by the Association, as can be seen from the very first moment, on the cover of the first issue, as well as in the editorials of certain commemorative editions. The initial greeting states that the journal Organització is created with a sense of loyalty and professional rapport, as a collective development of the sector with a commercial spirit, which is considered essential for the development of society.

The title "Organitzacio" was chosen because of the principles of industrial organization based on the division of labor, especially for the management functions of organizations. It mainly seeks rapport between associates and the employer class. In the corresponding sections, the Association was able to publicly show all the dealings related to its situation and the operation of its organization. 


\subsection{Structure}

As for its structure, basically each journal consists of:

- Front cover: With a discreet title that shares space with the Association's emblem. Over all these years, the model of this title has only changed slightly on three occasions: July 1926, January 1929 and January 1931.

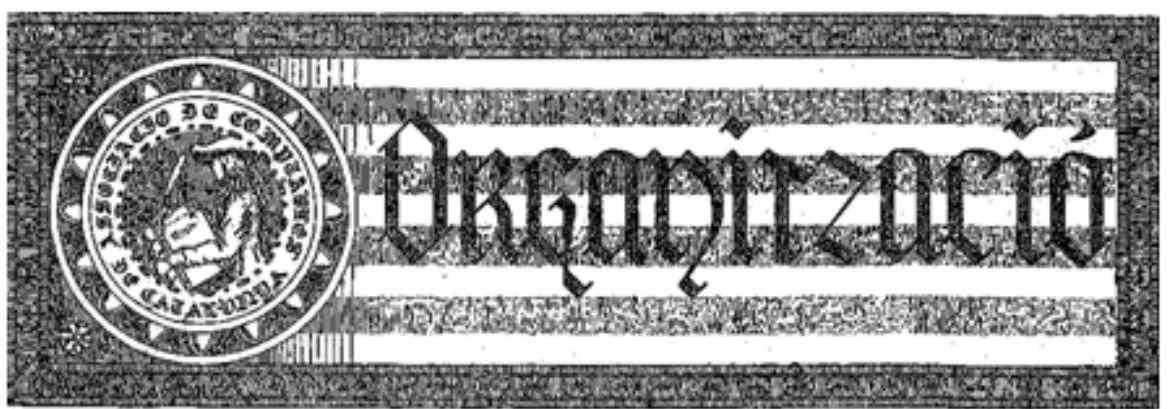

Figure 1. Cover of the journal Organització, 1925-1926

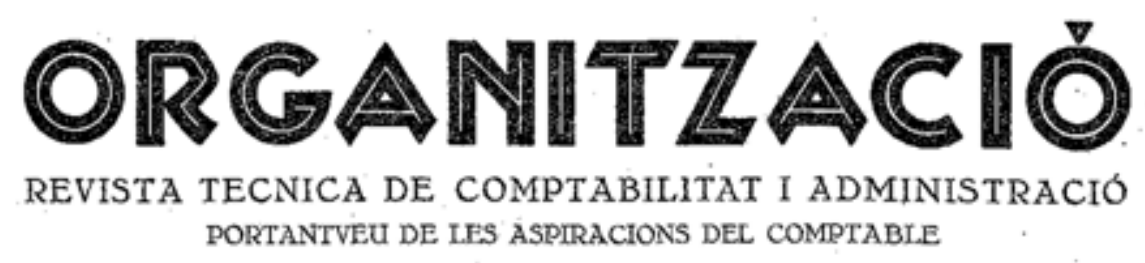

Figure 2. Cover of the journal Organització, 1931-1938

- Summary: The organized content of the sections is displayed on the front page, after the title, following the same order in which they appear in the content.

- Editorial: Presents a list of anniversaries in special issues, while in other cases, it presents an article.

- Articles: These are the most important part of the journal. They constitute the main core of information for the reader. The title summarizes the topic to be discussed. If it is considered that more information is needed, a subtitle might be added, although this rarely occurs. These texts are sometimes accompanied by illustrations to make the subject more understandable.

- Texts: The design is just as essential as the content of the articles, since in the journal the way in which the information is transmitted is very important.

- Advertisements: The advertisers are professionals or companies in the sector, which in part financially support the publication of each issue of the journal in exchange for being able to promote their product.

- Back cover: Explains the objective of the association and describes its structure.

- Index: It is presented at the end of each year in order to list the subjects contained in the journal during that period.

In order to be able to proceed to the study of the issues of the Journal in a uniform and homogeneous manner, to carry out the detailed analysis of every published issue, and as commented in the section on the methodology used, it was agreed to develop a common structure for the data sheets. Each of them includes basic identifying information: 
- journal issue;

- date;

- $\quad$ summary, with which we can record the different sections and in the case of articles, cite the title and author of the article;

- description of the contents. This section consists of three distinct points. The first lists the different articles with a short summary to present the subject matter. In the second, information of interest to members is presented, in addition to answers to questions submitted, books on economics and business to increase business knowledge, informative details of the different divisions of the Association Foreign Relations Division, Technical and Advisory Division, Legal-Administrative Division, Job Bank Division, Library Division, Mosaic - and variations. The third section presents any relevant observations;

- finally, the author of the summary.

The basic design of the data sheet is presented in Appendix A.

\subsection{Other aspects of the journal to highlight}

The bibliography section lists books that the Association received to organize a good professional library, with critical studies of these books to guide the reading.

It is also possible to verify how the language has evolved over time. Accordingly, in this journal written in Catalan, we can find many words and expressions that seem peculiar to us today.

When reviewing the different issues, the great effort and interest employed to make the publications internationally known are evident. On this note, in issue three are works published in France and in Italian, Belgian, Swiss and Austrian journals.

The journal evolved over time, and we can see how, starting with issue number 100 of January 1934, specific regulations published in the Boletin de la Generalidad [Official Regional Gazette] are presented, in line with the historical situation that Catalonia was experiencing.

A section of the journal called "Mosaic" provided a humorous point of view on various accounting topics, such as comments on accounting techniques, referring to the tasks of the accountant's work and environment.

The advertisements published contrast with those of today, probably because of the habits and customs of the time. The qualities of the product are emphasized and no reference is made to the emotions and desires of the users, as is the case today. See Figure 3. On another note, only one advertiser appears until issue number 19. From that moment on, other companies make their products known through this publication.

The Journal also reports "good news," for example that Monsieur René Delaporte received the silver medal from the French Accounting Society. It also has an obituary space. Both technical training and the attitude and skills required to carry out any activity are valued. Specifically, the people who are part of the "Job Bank" are considered to be of absolute competence and morality, as stated on page 147 of journal issue number 7 .

The end of each of the monthly issues states "This issue has passed through government censorship" or bears the inscription "endorsed by censorship". 


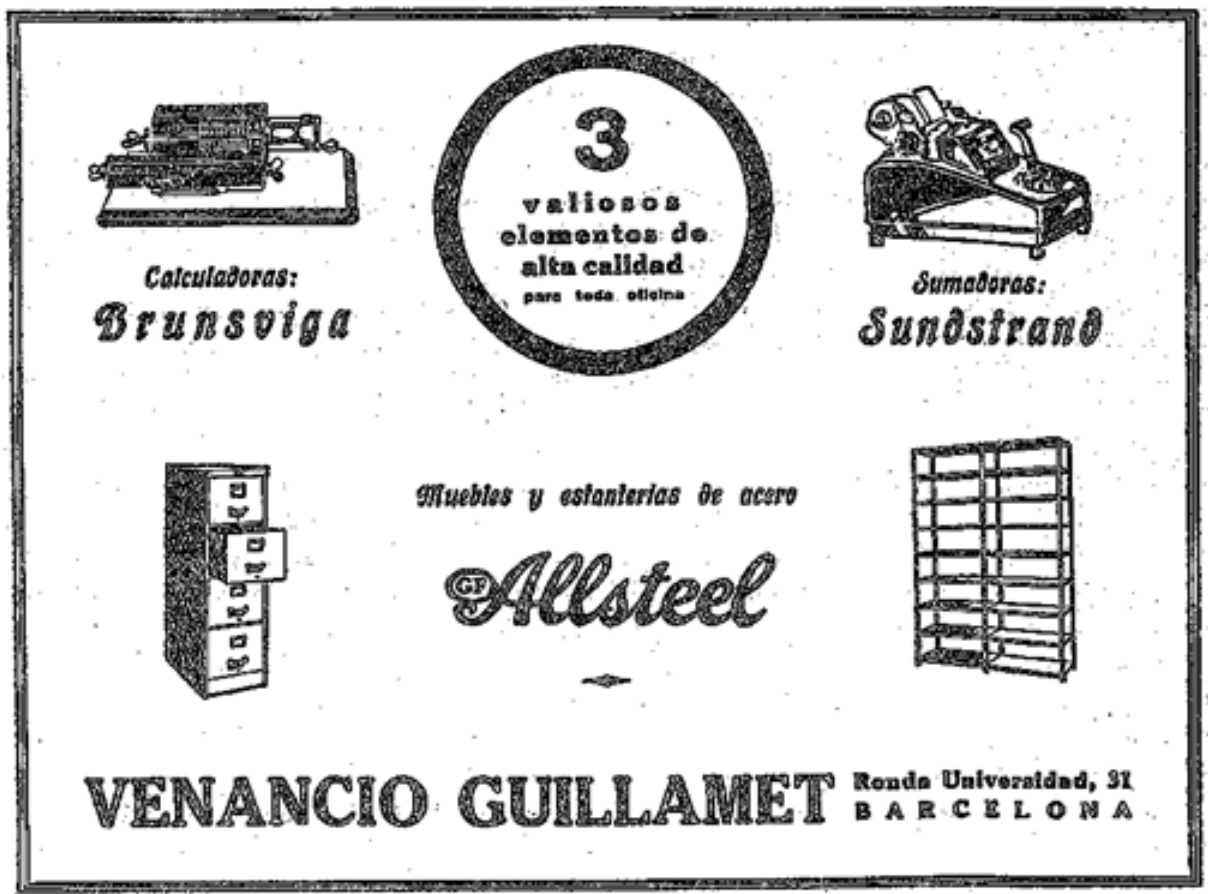

Figure 3. Advertisement. First advertiser

\section{Contents of the journal Organització: Results and discussion}

The contents of the journal Organitracio make reference to fourteen topics and highlight five thematic areas: Accounting records (22\%), Commercial Law and Taxation (20\%), Economics (15\%), Associationism in the business field and especially in the accounting field (11.5\%) and Business Organization (19\%) (Table 1).

Likewise, it should be noted that the journal focuses on the role of the accountant $(9 \%)$, i.e., it is a journal that deals with the role of the accountant as a leading professional in the companies of the time with economic activity between 1925 and 1938. See Figure 4. In the early years, emphasis was placed on the role of these professionals, but after the 1929 World Expo, subsequent issues of the journal no longer dealt with this type of subject matter.

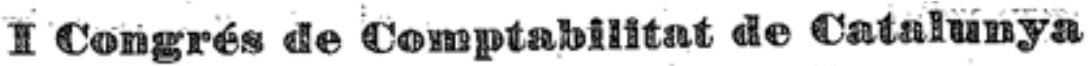 \\ Barcelona-23, 24, 25, $i 26$ setembre 1926 \\ Entltat organiteadora "Associació de Comptables de Catalunya"}

\section{Comitè Executiu.}

Antoni Planas Babra, Presidert; Andreu Buusili, Vis-president primer; Agusti Gomez Pons, Vis-president segon; Rafel Bori, Secretari general; Josep Coral Alejaldre Vis-secretari primer; Joan Ribas, Vis-secretari segon; Joan Guilera Mareugat, Tresorer; Angel U riarte, Vocal de premsa; Antoni Cabré, Marcell Paseual Torres, Eduard Borratxero, Vocals, furat qualificador.

Pere Corominas Montaña, Rafel Gay de Montella, Miquel Vidal i Guardiola, Ramon Guell, Pere Gual Villaibi, Josep M. Tallada, Ferran Boter, Bartomeu Amengual, Joaquim Aguilera, Fevrán Cuito. Josep Ėstengués, Rossend Serra i Pagès, Joan Creixells, Manuel
Pugés, Manuel Ainaud, Josep Zendrera, Josep Omar Gelpi, Cristofor Masó Escófet, Joaquím Coderch Niella, Jaume Algarra Postius; Francesc Rodon.

Comite d'admisió $i$ classificació de treballs. Antoni Planas Babra, President; Rafel Bori, Secretari; Marcell Creixell i Llopart, Vocal Vis-secretari; Andreu Bausili, Pere Verzier, Manuel Francitorra, Joan de Deu Mora, Joan Revoltos, F. de P. Gonzalez Palou, Vocals.

Comite d'organitzacló d'äctes.

Josep Coral Alejaldre, Prosident; Amadeu Gomez Pons, Secretari; Jośep Guilera, Enric Benet, Iguasi Delhom Llurià, Josep. Coral Jaumot, Bru Medallo Serrano, Vocals.

Figure 4. Organization of the first Congrés de Comptabilitat de Catalunya [Catalonian Accounting Conference] 


\begin{tabular}{|l|r|}
\hline Topics discussed in the journal Organització & $\mathbf{\%}$ \\
\hline Accounting records & $22.0 \%$ \\
\hline Economics & $15.0 \%$ \\
\hline Associationism & $11.5 \%$ \\
\hline Commercial law & $10.0 \%$ \\
\hline Taxation & $10.0 \%$ \\
\hline Business organization & $10.0 \%$ \\
\hline Role of accountants & $9.0 \%$ \\
\hline Banking management & $4.0 \%$ \\
\hline Costs & $3.5 \%$ \\
\hline Economic and accounting history & $2.0 \%$ \\
\hline Finance & $1.0 \%$ \\
\hline Training & $1.0 \%$ \\
\hline Insurance and mutual society services & $0.5 \%$ \\
\hline Budgets & $0.5 \%$ \\
\hline Total & $100.0 \%$ \\
\hline
\end{tabular}

Table 1. Topics discussed in the journal Organitració

It should be noted, that in the period 1928-1933, the most covered areas in the journal Organitracio were: associationism, commercial law, taxation, business organization and accounting records; but as we move closer to the Spanish Civil War (1936-1939), the articles, in line with the historical situation, dealt with subjects directly related to the economy of the country at that time, although as an accounting publication, it also included articles that made reference to the accounting records, but with less of a presence in their summaries.

With regard to the legal aspect, the journal also places special emphasis on this subject, in line with the area of accounting knowledge. Specifically, $20 \%$ of the articles in the journal Organització were related to this subject, which is important and prominent at the time, especially at the commercial and tax levels.

The journal also demonstrates a philosophy of operating and organizing companies and reflects the importance of associationism that was so present in Catalonia.

In the journal, the international vocation is highlighted with the organization of the first International Accounting Conference, taking advantage of the 1929 World Expo in Barcelona, where several European nations participated (Germany, Belgium, Denmark, France, Hungary, Italy, Norway, Romania and Switzerland), as well as private exhibitors from Japan and the United States. This World Expo presented technological advances and projected the image of Catalan industry aboard, so it was a great occasion for this journal in the field of business.

The urban development of the city at that time also facilitated an important economic activity that required knowledge such as that offered by the journal Organitzacio, especially in the area of economics, which corresponds to the $15 \%$ of the overall topics of the articles.

The 1929 World Expo in Barcelona is especially reflected in issues of the journal dedicated, in large part, to this important event of great economic significance for the city of Barcelona, and Catalonia in general.

Thus, the journal Organitració was an ideal means of communication to verify the economic reality of that moment and the processing to be followed on an accounting level to correctly reflect and record the business reality of the time. In this sense, in the issues from 1929 and 1930, topics such as the economy, taxation, the role of the accountant and the appropriate accounting records stand out.

Regarding the authors who published articles in the journal Organitzacio, it should be noted that they were probably members or experts in accounting matters. A total of 596 articles were published from 1925 to 1938, by a total of 237 authors. Table 2 shows a list of names and surnames of the authors who published a number of articles equal to or greater than 7. It includes a total of 21 authors, representing a $37 \%$ of the total number of articles published by the journal. The remaining $63 \%$ are articles by a number of authors who published fewer than 7 articles. 


\begin{tabular}{|c|c|c|c|c|}
\hline Names and surnames of the authors & $\begin{array}{l}\text { Total no. of } \\
\text { articles } \\
\text { published }\end{array}$ & $\%$ & $\begin{array}{l}\text { Date of first } \\
\text { article }\end{array}$ & $\begin{array}{l}\text { Date of last } \\
\text { article }\end{array}$ \\
\hline ALSINA, Jaume & 11 & $1.85 \%$ & $02 / 1929$ & $02 / 1931$ \\
\hline ARBOLÍ, Pere & 7 & $1.17 \%$ & $06 / 1930$ & $03 / 1933$ \\
\hline ARDANUY, Pere & 9 & $1.51 \%$ & $07-08 / 1931$ & $11 / 1934$ \\
\hline BELTRAN PRATS, Faust & 7 & $1.17 \%$ & $01 / 1929$ & 03-04-05/1938 \\
\hline BORI, Rafel & 9 & $1.51 \%$ & $08 / 1925$ & $10 / 1935$ \\
\hline CARALT ROCA, Joan & 7 & $1.17 \%$ & $02 / 1928$ & $03 / 1931$ \\
\hline FELIU CODINA, Antoni & 11 & $1.85 \%$ & $09 / 1927$ & $01 / 1938$ \\
\hline FRANCITORRA ALEÑ்̀, Manuel & 24 & $4.03 \%$ & $02 / 1926$ & $03-04-05 / 1938$ \\
\hline GARDÓ, Josep & 12 & $2.01 \%$ & $02 / 1927$ & $06-07 / 1933$ \\
\hline GAY DE MONTELLȦ, Rafael & 7 & $1.17 \%$ & $09 / 1925$ & $03 / 1932$ \\
\hline GENÉ JOVÉS, Miquel & 7 & $1.17 \%$ & $01 / 1927$ & $01 / 1928$ \\
\hline GÓMEZ PONS, Agustí & 8 & $1.34 \%$ & $09 / 1925$ & $01 / 1929$ \\
\hline HERNÁNDEZ CABEZA, Pere & 13 & $2.18 \%$ & $05 / 1931$ & $09 / 1932$ \\
\hline MIRACLE, Joan & 7 & $1.17 \%$ & $08 / 1926$ & $02 / 1934$ \\
\hline OBACH POL, A. & 15 & $2.52 \%$ & $05 / 1926$ & $03 / 1931$ \\
\hline PACH BUIRA, Antoni & 7 & $1.17 \%$ & 08/1928 & $05 / 1935$ \\
\hline PIQUÉ BATLLE, Ricard & 24 & $4.03 \%$ & $07 / 1926$ & $03-04 / 1936$ \\
\hline PLANAS BABRA, Antoni & 10 & $1.68 \%$ & $08 / 1925$ & $12 / 1926$ \\
\hline REVOLTÓS, Joan & 10 & $1.68 \%$ & $08 / 1925$ & $06 / 1934$ \\
\hline VILÀ, Josep Maria & 8 & $1.34 \%$ & $10 / 1928$ & $03-04-05 / 1938$ \\
\hline ZENDRERA, Enric & 9 & $1.51 \%$ & $02 / 1930$ & $05 / 1931$ \\
\hline Other authors & 374 & $62.75 \%$ & & \\
\hline Total number of articles published & 596 & $100.00 \%$ & & \\
\hline
\end{tabular}

Table 2. List of authors who published the most articles in the journal Organització

Hence, as shown in Table 2, the authors who published the most articles are: Manuel Francitorra Aleñà, president of the Associació de Comptables de Catalunya (ACC) in two different periods, and Ricard Piqué Batlle. Some authors published under a pseudonym.

\section{Comparison of the ACC and ACCID: Results obtained}

The purpose of this section is to carry out a comparative study between the ACC and ACCID, analyzing different aspects: formation and purpose, activities, organizational structure, members and commissions/sections. These two associations have a lot in common, despite the time differences. It should be kept in mind that the ACC ceased its activity in 1940, with the end of the Spanish Civil War and the beginning of General Franco's new regime, and the ACCID was not created until more than sixty years later. In addition, the relationships that the ACC established with other international accounting associations are also mentioned in this section.

\subsection{Formation and purpose}

As shown in Table 3, these two associations were founded nearly 80 years apart: the ACC at the beginning of the 20th century (1924) and the ACCID in the early 21st century (2002). While ACC was founded at the initiative of civil society, the ACCID was the product of the will and actions carried out by three professional associations. Even so, it is good to emphasize that the basic purpose of the two associations is the same: to serve as a meeting point between professionals and scholars associated with the world of accounting. Regarding the location, the ACC created local divisions in LLeida and Igualada (1927), and in contrast, the ACCID has its headquarters only in Barcelona. Furthermore, it should also be noted that the activity of the ACCID is currently complemented by the tasks carried out by the different chartered institutes and professional associations. 


\begin{tabular}{|l|l|}
\hline Formation and Purpose \\
\hline ACC & ACCID \\
\hline - Founding: In Barcelona, on February 12,1924. & - Founding: In 2002 by the Association of Sworn \\
- End of its activity: In 1940. & Accounts Auditors of Catalonia, the Association of \\
- Aim: To debate and work on the accounting & Economists of Catalonia, the Association of Qualified \\
issues of the time, among accounting & Financial Experts and Entrepreneurs of Barcelona. \\
professionals and employees, in the field of & They were later joined by the Association of \\
business and industry in Catalonia. & Secretaries, Financial Controllers and Treasurers of \\
- Local divisions in Lleida and Igualada & Catalonia and the Official Association of \\
in 1927. & Administrative Managers of Catalonia. \\
& $\begin{array}{l}\text { - Aim: To serve as a connecting link between } \\
\text { professionals and scholars who work in Catalonia in } \\
\text { the field of } \\
\text { accounting. }\end{array}$ \\
\hline
\end{tabular}

Table 3. Comparison of the ACC and the ACCID: Formation and purpose

\subsection{Activities}

The activities carried out by the two associations are fairly similar. Both organized courses, events and conferences, congresses and seminars, and edited and published books and documents. While the ACC took advantage of the journal Organització to disseminate information to its members, the ACCID makes use of the new technologies and thus communicates with members through its website and newsletters. As something that sets the ACC apart, it should be mentioned that its members created their own library and were able to submit free consultations associated with accounting and other related fields. The association also sponsored a job bank and offered mutual society services and assistance for members in matters related to employment contracts. Furthermore, in an action that was very progressive for the era, the ACC saw the need to establish relationships with other accounting associations on an international level.

Specifically, the ACC maintained contact with different accounting associations in different countries, such as the Institute of Chartered Accountants of England and Wales (ICAEW) in Great Britain, the first accounting organization founded in 1854. The Institute of Chartered Accountants of England and Wales was considered to be very prestigious. This institution currently has more than 150,000 members, including some outside the United Kingdom. Many students are also members and 80 of the companies on the FTSE 100 stock exchange (the main companies in the United Kingdom) have accountants recognized by this association.

It must be kept in mind that until the middle part of the 19th century, the role of accountants in England and Wales was restricted to those who kept purchasing and sales records. With the growth of the limited liability companies, and large-scale manufacturing and logistics in Great Britain, more technically competent accountants were required to deal with the growing complexity of account operations. As a result, the accountants in the cities of Great Britain formed professional organizations and the ICAEW was created from five different associations already in existence in England.

The members of this association are currently recognized accountants who have the ACA qualification, which is granted with the opportune work experience (three to five years) and after having passed different exams. During the training of accountants, the institution oversees ethical matters and the corresponding professional commitment to them, in such a way that Chartered Accountants (ACA) of the ICAEW are very highly valued in the public and private sector around the world.

The ACC maintained contact with other accounting associations in France and northern Africa. It also maintained contact with the International Accounting Association, as evidenced by the joint organization of the 6th International Accounting Conference in Barcelona in 1929 by the ACC and the International Accounting Association. It also had a relationship with the Official Accounting Diploma Institute of Paris, the Academic Accounting Society of Belgium and the International Accounting Association of Brussels (Alemany \& Rabasseda; 2016). 
With regard to the ACCID, one of the activities it carries out, unlike the ACC, is the giving of awards and subsidies to support research in different categories. One somewhat anecdotal fact, but one that was very normal for the time, was that the activities of the ACC were carried out at night, as shown in Table 4.

\begin{tabular}{|l|l|}
\hline Activities & ACCID \\
\hline ACC & - Events and conferences. \\
\hline - Courses (accounting, arithmetics, statistics, law, & - Organization of the Catalonian Conference on \\
economics, etc.) and conferences. & Accounting and Management (held once every two \\
- Own library for members. & years). See Appendix C. \\
- Dissemination activities through the journal & - Organization of the ACCID Seminar (held once \\
Organització. & every two years, alternating with the scheduling of the \\
- Free responses to consultations from its & Conference). \\
members. & - Sending of a newsletter. \\
- Links to international accounting institutions & - Publishing of books and other publications \\
(English/French). & specialized in accounting and business administration. \\
- Publishing of books, brochures and documents & - Issuing of declarations on accounting problems. \\
and the journal Organització. & - Publication of accounting regulations, revisions and \\
- Job bank with offers and demands. & updates. \\
- Mutual society services to cover illness, & - Awards and aid for research. \\
disability and death and a clinical service. & - Debate forums on current accounting topics. \\
- Assistance for members in matters related to & \\
employment contracts, job search and & \\
unemployment subsidies. & \\
\hline
\end{tabular}

Table 4. Comparison of the ACC and the ACCID: Activities

\subsection{Organizational structure}

In both associations, the top level of management corresponds to the Management Board or Council. It consists basically of the president, vice-presidents (1 from the ACC and 3 from the ACCID), secretary, chairpersons and treasurer. The ACC includes the figure of the bookkeeper and that of a substitute chairperson, while the ACCID has the position of an undersecretary and directors. In the case of the ACC, the procedure followed for the election of the members of the Governing Board corresponding to the General Council is a secret vote of active members in attendance with more than 6 months of seniority. The President is appointed by the General Council. Only active members form part of the Governing Board, which is normally renewed every year. As can be observed in Table 5, the ACC had five presidents during its existence, while the ACCID has had three. In both associations, these positions have been held by men.

\begin{tabular}{|l|l|}
\hline Organizational structure \\
\hline ACC & ACCID \\
\hline $\begin{array}{l}\text { The Governing Board is the top management } \\
\text { body. It consists of: President, Vice-president, } \\
\text { Secretary, Bookkeeper, Treasurer, nine Delegate } \\
\text { Chairpersons and a Substitute Chairperson. }\end{array}$ & $\begin{array}{l}\text { The top management body corresponds to the } \\
\text { Management Board, the function of which is to } \\
\text { govern, manage and represent the association. It } \\
\text { consists of: President, 1st Vice-president, 2nd Vice- } \\
\text { president, 3rd Vice-president, Secretary, }\end{array}$ \\
$\begin{array}{l}\text { Presidents of the ACC: Antoni Planas (1925), } \\
\text { Andreu Bausili (1927), José A. Vandellós (1929), } \\
\text { Manuel Francitorra (1933), Antoni Feliu (1934) } \\
\text { and Manuel Francitorra (1936). }\end{array}$ & $\begin{array}{l}\text { Directors. } \\
\text { Presidents of the ACCID: Ferrán Termes (2002- } \\
\text { 2013), Oriol Amat (2013-2018) and Daniel Faura } \\
\text { (2018-present). }\end{array}$ \\
\hline
\end{tabular}

Table 5. Comparison of the ACC and the ACCID: Organizational structure

\subsection{Members: Types and benefits}

Table 6 provides the corresponding comparison: 


\begin{tabular}{|l|l|}
\hline \multicolumn{2}{|l|}{ Members: Types and benefits } \\
\hline ACC & ACCID \\
\hline - Two types of members: patrons, active and & There are two types of members: full members and \\
auxiliary. & patrons. \\
- Active member: a member of the accounting & Benefits: \\
profession. & - Free attendance at conferences, book presentations, \\
- Aspiring members: young accounting students. & seminars and events. \\
Benefits of membership: & - Special prices and discounts for the purchase of \\
- Course and conference attendance. & books published by the ACCID. \\
- Access to the association's library. & - Sending of electronic newsletters. \\
- Free technical consultations on different & - Technical consultations. \\
subjects. & - ACCID work commissions. \\
- Congress attendance. & - Information on the latest news in accounting \\
- Contact with international associations. & regulations. \\
- Exchanges with international journals. & - Information and discounts on training programs \\
- Book publication. & offered by affiliated organizations. \\
- Information through the journal Organització. & - Attendance at the Accounting and Management \\
- Participation in the journal Organització. & Conference and ACCID Seminar. \\
- Continuous information about the accounting & \\
profession and the job bank. & \\
- Access to mutual society services & \\
(Brotherhood of the Association of & \\
Accountants of Catalonia). & \\
\hline
\end{tabular}

Table 6. Comparison of the ACC and the ACCID: Members: Types and benefits

Both associations include two types of members: patron members and full or active and auxiliary members, with different benefits in each case, but also with a different relationship in terms of the association. In the case of the ACCID, it was possible to find more detailed information on the benefits of the different types of membership. Patron members consist of Catalonian universities and business schools, public administrations, chambers of commerce, employer organizations, social agents, businesses, and auditing and consulting firms (Table 6). These members have the same benefits as full members, plus a few additional ones. There was a very positive evolution in the number of ACC members, increasing from 83 in 1924 to 797 in 1930. In the ACCID, there are currently 11,494 members, including full members, associate members and patrons.

\subsection{Commissions/Divisions}

While the ACC is organized into divisions, in the ACCID, we find commissions. The divisions of the ACC refer to specific tasks and activities performed by the association, while the ten work commissions of the ACCID are associated with specific topics, basically related to the area of accounting where research and research documents are being developed.

\begin{tabular}{|l|l|}
\hline Commissions/Divisions \\
\hline ACC & ACCID \\
\hline 9 divisions: & 10 work commissions: \\
1. Organization and Internal Regime Division & 1. Accounting \\
2. Library and Bookstore Division & 2. Management Accounting \\
3. Advertising and Publicity Division & 3. Co-operative Accounting and non profit entities \\
4. Technical-Advisory and Legal-Administrative & 4. Public Accounting \\
Division & 5. Intangible Assets \\
5. Foreign Relations Division & 6. Organization and information systems \\
6. Publications Division & 7. Accounting-Taxation Relations \\
7. Job Bank Division & 8. Social responsibility \\
8. Mutual Society Services Division & 9. Company valuation \\
9. Social-Professional Division & 10. Professors of Accounting and Control \\
\hline
\end{tabular}

Table 7. Comparison of the ACC and the ACCID: Commissions/Divisions 


\section{Conclusions}

The priority objective of this study has been to conduct an exhaustive analysis of the most important features of the journal Organitració, published during the period 1925-1938 by the Association of Accountants of Catalonia (ACC).

This study has made it possible, on the one hand, to document the activities performed by the Associacio de Comptables de Catalunya (ACC), created in 1924, and draw certain parallels to the current Associació Catalana de Comptabilitat I Direcció (ACCID), created in 2002, and on the other hand, to gain in-depth knowledge of the characteristics of the journal Organitració.

The purpose of the ACC was to create a space to debate and delve deeper into accounting topics, both by professionals and employees in the commercial sector. Among the many activities performed by the Associacio de Comptables de Catalunya, we can highlight the following: the publication of books and documents in the area of accounting, as well as the journal Organització, training activities and consulting by members, book lending, a job bank and mutual society services for members and their families.

The study presented here allows us to conclude that the journal Organització was both professional and academic in nature, as it offered insight into accounting topics by both professionals and scholars alike. It was published on a monthly basis and was specialized in accounting and business topics.

The main topics dealt with in the journal refer to accounting records, commercial law and taxation, economics, associationism and business organization, among others. Of the authors publishing the most articles in the journal, of particular interest are Manuel Francitorra (president of the ACC from 1931-1933 and 1936-1940) and Ricard Piqué Batlle (who became a member of the Royal Academy of Economic and Financial Sciences and served as its president in 1947).

Furthermore, the journal Organitzacio has made it possible to know about the existence of different types of members, such as patron members, active members and auxiliary members, and to know the requirements that needed to be met to become a member.

We can therefore conclude that, except for the differences that can be found in society and the profession in each time period, there is a certain parallelism between the activities carried out by the ACC at the start of the 20 th century and the activities currently performed by the ACCID at the start of the 21 st century. This includes both serving as a meeting point for professionals and scholars in the business sector, and more specifically, in the accounting and financial sector, on both a national and international level. This is in addition to the publication of books, journals and various types of informative documents and the organization of seminars, conferences and congresses in this field of knowledge. This highlights the driving force that these two associations have been in accounting for Catalonia.

\section{Declaration of Conflicting Interests}

The authors declared no potential conflicts of interest with respect to the research, authorship, and/or publication of this article.

\section{Funding}

The authors have received the support of ACCID to carry out this study.

\section{References}

Allais, M. (1938). Les fondements comptables de la macroeconomie. Paris: P.U.F.

Allais, M. (1956). Traité d'économiepure. Revue écononomique, 7(3), 489-490. https://doi.org/10.2307/3497783

Amat, M. (2014). Associació de Comptables de Catalunya (1924-1940). Revista de Catalunya, 288, 73-84.

Associació de Comptables de Catalunya (Ed.). (1925-1938). Organització (Revista Tècnica de Comptabilitat i Administració). Numbers: 1 to 149. 
Associació de Comptables de Catalunya (1929). VI ${ }^{\circ}$ Congreso Internacional de Contabilidad. Llibre del Congrés. Barcelona.

Carmona, S. (2004). Accounting history research and its diffusion in an international context. Accounting History, 9(3), 7-23. https://doi.org/10.1177/103237320400900302

Degos, J.G., \& Mattessich, R. (2003a). La litterature comptable francophone (1900-1950) et les risques d'une periode chaotique. Identification et maîtrise des risques: Enjeux pour l'audit, la comptabilité et le contrôle de gestion. France. pp. CDRom, $2003<$ halshs-00582765>

Degos J.G., \& Mattessich R. (2003b). Accounting Research in the French Language Area: The First Half of the 20th Century. Review of Accounting \& Finance 2(2), 110-128. https://doi.org/10.1108/eb043394

Félix, E.E. (2011). Paul Otlet (1868-1944) et l'Association Internationale de Comptabilité AIC. Groupement Francophone des Professionnels de la Comptabilité, 4, 10-12.

Forrester, D.A. (1992). Historia revisada de los Congresos Internacionales de Contabilidad. Revista Española de Financiación y Contabilidad, 72, 527-549.

Küpper, H.U., \& Mattessich, R. (2005). Twentieth century Accounting research in the German Language area. Accounting, Business \& Fianancial History, 15(3), 345-410. https://doi.org/10.1080/0958520050084310

Lemarchand, Y., \& Praquin, N. (2005). Falsifications et manipulations comptables. La mesure du profit, un enjeu social (1856-1914). Comptabilité - Contrôle - Audit, 11(3), 15-33. https://doi.org/10.3917/cca.113.0015

Vlaemminck, J.H. (1961). Historia y doctrinas de la contabilidad: Estudios jurídicos, económicos y sociales. Barcelona; E.J.E.S.

\section{Appendixes}

Appendix A

Model technical data sheet

\section{ACCID ACCID ACC \\ Arup de recerca sobre \\ 1'ASSOCIACIÓ DE COMPTABLES DE \\ CATALUNYA (1924-1940) [Catalonian \\ Accounting Association research group]}

\begin{tabular}{|l|l|}
\hline \multicolumn{2}{|c|}{ TECHNICAL DATA SHEET: JOURNAL ORGANITZACIÓ } \\
\hline Journal issue & \\
\hline Date & \\
\hline Summary & \\
\hline
\end{tabular}

DESCRIPTION OF THE CONTENT

a) Articles

b) Other sections

c) Notes

Summary sheet completed by: 


\section{Appendix B}

Number of issues of the journal Organització

\begin{tabular}{|l|l|r|}
\hline Year & Journal elements & Issues \\
\hline 1925 & 6 & 1 to 6 \\
\hline 1926 & 12 & 7 to 18 \\
\hline 1927 & 12 & 19 to 30 \\
\hline 1928 & 12 & 31 to 42 \\
\hline 1929 & 10 (combining the months & 43 to 54 \\
\hline & September-October and November-December) & 55 to 66 \\
\hline 1930 & 12 & 67 to 78 \\
\hline 1931 & 11 (combining the months July-August) & 79 to 90 \\
\hline 1932 & 12 & 91 to 99 \\
\hline 1933 & 9 (combining the months June-July; August-September and November- & 100 to 111 \\
\hline 1934 & December) & 112 to 123 \\
\hline 1935 & 12 & 124 to 134 \\
\hline 1936 & 11 (combining the months March-April) & 135 to 146 \\
\hline 1937 & 12 & 147 to 149 \\
\hline 1938 & 3 (combining the months March-April-May) & \\
\hline
\end{tabular}

\section{Appendix C}

\section{Conferences held by the ACC}

\begin{tabular}{|l|r|}
\hline Conferences & Year \\
\hline 1st Catalonian Accounting Conference (national) & 1926 \\
\hline 6th International Accounting Conference (Barcelona) & 1929 \\
\hline
\end{tabular}

\section{Conferences held by the ACCID}

\begin{tabular}{|l|l|l|}
\hline Conferences & Year & University \\
\hline 1st Conference & 2005 & University of Barcelona \\
\hline 2nd Conference & 2007 & IESE Business School \\
\hline 3rd Conference & 2009 & ESADE Business School \\
\hline 4th Conference & 2011 & PompeuFabra University \\
\hline 5th Conference & 2013 & International University of Catalonia \\
\hline 6th Conference & 2015 & AbatOliba CEU University \\
\hline 7th Conference & 2017 & IESE Business School \\
\hline
\end{tabular}

\section{Seminars held by the ACCID}

\begin{tabular}{|l|r|l|}
\hline Seminars & Year & College/University \\
\hline 1st Seminar & 2010 & $\begin{array}{l}\text { College of Economics and Business - Autonomous University of Barcelona } \\
\text { (Sabadell Campus) }\end{array}$ \\
\hline 2nd Seminar & 2012 & College of Economics and Business - RoviraiVirgili University \\
\hline 3rd Seminar & 2014 & College of Economic and Business Sciences - University of Girona \\
\hline 4th Seminar & 2016 & College of Law and Economics - University of Lleida \\
\hline 5th Seminar & 2018 & $\begin{array}{l}\text { College of Business and Communication - Vic University - Central University of } \\
\text { Catalonia }\end{array}$ \\
\hline
\end{tabular}

